\title{
RELIGIOUS INTERPRETATION ON PANCASILA METHODOLOGICALLY AND EMPIRICALLY IN IMPLEMENTING ISLAMIC INSIGHT IN INDONESIAN ARCHIPELAGO
}

\author{
Wahyudin \\ State Islamic Institute of Metro \\ East Metro, Metro, Lampung, 34112, Indonesia \\ E-mail:wahyudinyudi34@yahoo.com
}

\begin{tabular}{c|c|c}
\hline Received: & Revised: & Approved: \\
28/04/2019 & $17 / 06 / 2019$ & $26 / 06 / 2019$ \\
\hline
\end{tabular}

DOI: http://dx.doi.org/10.32332/akademika.v24i1.1615

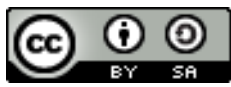

Religious Interpretation On Pancasila Methodologically And Empirically In Implementing Islamic Insight In Indonesian Archipelago Licensed Under a Creative Commons Attribution-ShareAlike 4.0 International License

\begin{abstract}
Religious interpretations of Pancasila in implementing Islamic insights result from interpretations of religious teachings. For example, the interpretation of the principles of Indonesian unity is the Islamic ummah. The Indonesian context of the unity of all nations in the archipelago is a unity; Indonesian people with BhinekaTunggallka ties. Indonesia is a great nation since the Kingdom of Srivijaya, Majapahit with Palapa pledge is strong, strong and advanced and respected by other countries. The kingdom collapsed not because of an external threat, but it was damaged from the inside. The Indonesian nation at present is a great nation, in essence feared by foreign countries. Indonesia cannot be bombarded from the outside. The method of infiltration into various ways; liberalism, secularism, 'radicalism, fundamentalism and so on. This country is prosperous, "gemah ripah loh jinawi" should be toto tentrem kerto raharjo. The source of his wealth is the struggle of foreign countries no matter how and how. Our present and future duties are to defend the sovereignty of the Republic of Indonesia in any way. The fact is that government policies tend to side with foreigners. If you are not vigilant early on, the Indonesian nation can be lost. For example, in Singapore, Malay tribes were destroyed,
\end{abstract}


American Indians were marginalized, Australia aboriginal tribes were isolated, Palestinians had no territory. Jakarta Betawi tribes began to be evicted.

Keywords: Interpretation, Islam, Pancasila and implementation

\section{A. Introduction}

The reality of socio-cultural life of Indonesia shows that the nation of Indonesia is a religious nation, a nation that believes in God's Almighty. Therefore, the growth and development of social life will be heavily influenced and coloured by religious values, therefore also religious and cross-religious life can't be separated from the Indonesian life.

Religion is the provisions of the God's Almightythat contains values of sublime, noble and sacred and is practiced and practised by the respective adherents who lubricated and influenced in the Indonesian effort to continue their dreams. Namely to build an modern nation that is inspired by the values of the insight of the archipelago of the Almighty of God. ${ }^{1}$

The current phenomena that are widely embedded in the minds of religious minds and behaviours are that religious truths are singular, definite, and complete. They assume, that religion is the area that must be purified from human creativity and criticism. Therefore, religion is a territory of God that is assured of truth.

The religious interpretations that arise come from one direction, namely the interpretations of the religious institution. In addition, the existing religious interpretations are also too oriented towards the religious understanding of the vertical and legal-formal. This means that religious understanding relates to ritual worship, dogmatic, and associated with the consciousness of the heavens (deity). As the interpretation of the religious interpretation bi al-Dariyah which means to see, understand, think, count or suspect also can be interpreted with their faith (i'tiqad), sense of mind, ijtihad and even qiyas (analogy) ${ }^{2}$. It does not mean that the interpretation of the madzmun commentary is the tendency of lust built based on the ignorance and misguidance of translators ${ }^{3}$.

A single interpretation of religion is far from healthy because it will result in misappropriation of religious messages that originally meant

${ }^{1}$ Departemen Agama RI, Pedoman Dasar Kerukunan Hidup Beragama (Jakarta: Proyek pembinaan kerukunan DEPAG RI, 1984), 1.

2 Muhammmad Amin Suma, Studi Ilmu-Ilmu Alqur'an (Jakarta: Pustaka Firdaus, 2001), 71.

3 Muhammad Ali al Shabuni, al Tibyan fi Ulum al Qur'an (Dimaskus: Makatabah Al Ghazali, 1981), 155. 
noble. Because, the innate basic attitude of humans is not far from naivety, greed, and other subjugating passions. For example, in the concept of Christian interpretation there was the Catholic churches before the Second Vatican Council that suspended religious understanding as an exclusive by stating "There is no salvation outside the church". As a text, Pancasila has a diverse potential of interpretation. And Pancasila was born and grew up in Indonesia that has a diverse society that is surrounded by culture as well as its religion. This means that every class allows interpretation in the effort to interpret the Pancasila which is then proclaimed in the practice indaily life.

Because of Pancasila as the national principle andnusantaraideology is the source of all the sources of living philosophy that prevail in Indonesia. Then Pancasila as a view of life,the soul of personality, identity of the nation to achieve the goal that will be achieved by the nation of Indonesia as a noble agreement of the people of Indonesia is the ideals of Indonesia ${ }^{4}$. The existence of national life at all times always interact with the environment, bothinside and outside the environment. So that aspect can cause problems 5 .

In the era of New Order government Pancasila interpreted unilaterally to create a monopoly of interpretation. Then the ruler also forced it to the whole nation. A single interpretation sustained by strong power, does not want to be accepted by all components of the nation, voluntarily or forced. Though, there are also resistance's ripples against the hegemony but end in a terrible state. By the tumbles of new era powers, the singular interpretation of Pancasila will also be by itself.

Theoretically, the relationship between Pancasila and religion is a double. On one side can be Symbiose-mutualistic. Both can replenish and strengthen the nation's ethical and state. On the other hand, the two can compete as definitions of reality and fight for support. "tension " between Pancasila and religion can be semi-permanent, if religion is understood as an ideology (Islam addinwa-Daulah) and not as "Addin ". Religion can turn into ideology if it functions as legitimacy of power (quo-status). In order to realize the meaning of religion as a blessing for human beings, then there should be a shift of attitude, from the religious exclusive to an

${ }^{4}$ Moerdiono, Pancasila sebagai Idiologi Dalam berbagai Kehidupan Berbangsa dan Bernegara (Jakarta: Bp. 7 Pusat, 1992), 286.

5 LembagaKetahanan Nasional (Lemhanas), Ketahanan Nasional (Jakarta: Penerbit PT Balai Pustaka Dengan Lemhanas, 1997), 95. 
inclusive rational thought about the religion then out of cover and divider that makes no care against other concepts ${ }^{6}$.

Historically the tension between Pancasila and religion occurred since the country stood. The distortion of Pancasila at that time was more in the domination of its multiinterpretation. The contradictory liberal democracy and democracy, are equally engaged in Pancasila's democracy. In the period of new era government, Pancasila many experienced inconsistencies, tends to shift the role of religion (pseudo religion) and serve as legitimacy of power.

The hectic talking about the philosophy and basic of the country, on the one hand, signifies the nation's still attention to Pancasila who had had the decadence of authority in the reform era. At least the crowd showed not the death of the nation's concern for the foundations of nation-life and state. Actually, what is needed by this nation is a peace, because peace is a process of multidimensional combat that never ends in an attempt to change violence ${ }^{7}$.

Conceptual methodologically between Pancasila and the religion affects the view of thought in the Indonesian archipelago (nusantara). The reality of development in the archipelago from the strategic issue side indicated that the development and direction of general policy based on the Pancasila as the state ideologist. As a methodological field of religion aims to realize human and the quality of people who believe and fear to God Almighty in addition to create harmony and balance both in personal life and in relation to society in the Indonesian archipelago.

Empirically the problems that occur in life and society in the archipelago has not put the Pancasila as a basis or the principles in towards prosperity. The legitimacy of religion and customs are more dominant and very essential, the emergence of ideological ideology, fundamentalism, liberalism, religious secularism in the midst of society as the fire in the husk. He was still willing to sacrifice for himself, the group and partly portrayed power domination, as well as proposed rules inspired by religious teachings. Pancasila has lost energy to socialize itself. It is no longer a reference to state and ethnic action.

If looking at the textual interpretation (concept) related to the meaning of Pancasila social justice for the whole people of Indonesia and in the

6 Atosokhi Geanoor Rahcmat Antonius dan Panca Yuni Wulandari AntoniaAtosokhi Geanoor Rahcmat Antonius, Relasi dengan Tuhan (Jakarta: Gramedia, 2004), 360.

7 MutisThoby, Perdamaiandan anti Kekerasan, Merajut Mozaik Budaya bangsa (Jakarta: UniversitasTrisakti, 2007), 68. 
opening of the Constitution Act unified sovereign fair and prosperous it is correct, but in the context (reality) in The interpretation of Pancasila has been away from the concept. Interpretation of government policies that tend to be unfamiliar with foreigners. Feared if it is not alert since the early Indonesian state is still there, but the Indonesian nation will be lost, such as the country Singapore where Malay tribe was lost, in the United States of the Indians was knocked out, in Australia aboriginal tribeswas exiled, Palestine has a nation without territory.

The interpretation in order to open the eyes of the heart and inner eye that the archipelago has a wealth of abundant, Gemah ripah Loh Jinawi. whereas actually the state and nation of Indonesia Bhineka Tunggal Ika who inhabited the archipelago from Sabang to Merauke can sovereign fair and fair prosperous and prosperous. Because the Indonesian people who are friendly and polite, mutual understanding, Gotong royong A variety of religions can be used as a force. Some of these studies to deliver the interpretation of the religious majesty of Pancasila in order to know the textual conducted by researchers in the archipelago area including

First, Tri Yuliana Wijayanti, explaining the mutual understanding can only materialize with the earthing of religious interpretation that has a tolerance ${ }^{8}$.

Secondly, YuanggaKurnia explained the concept of the teaching of compassion in the world's major religions such as Islam, Christianity, Hinduism and Buddhism as a basis for the rejection of the use of violence on behalf of religions in the Earth. ${ }^{9}$

Thirdly, Ni WayanGateri, the teachings of Tat TwamAsi is the moral teaching of our people in life and everyday behavior of the human beings concerned by the wishes of human beings carrying out a sense of togetherness, so how severe the problems The face will feel light (Rwabhineda) is there and always side-by ${ }^{10}$.

Fourth, Nazwar, Confucius convinced that, although the fate of man is led by God or "T'ien", but the essence of the whole-life is human. Confucius taught his people about the role of "T'ien" which essentially leads humans into living life in the world. Jen also includes a humane feeling towards

8 Tri Yuliana Wijayanti, "Konsep Kebebasan Beragama Dalam Islam Dan Kristen" 17, no. No.1 (Juni 2016): 16-22.

${ }^{9}$ YuanggaKurnia Y, "Fenomena Kekerasan Bermotif Agama di Indonesia" 15, no. 2 (Desember 2017): 205-2017.

${ }^{10} \mathrm{Ni}$ WayanGateri, "Ajaran Agama Hindu Dalam Peningkatan Kerukunan Menuju Keharmonisan Hidup" 2, no. No. 2 (Agustus 2016): 93-108. 
others. These human feelings further lead people to be wise, like generosity, believing, and generosity ${ }^{11}$.

The religious interpretation on Pancasila, methodologically refers to the holyQuran, an and empirically what is now happening in the region of nusantara, as the author mentioned above the problems that occur contextually. The difference with previous research lies in the philosophical significance of normative religious interpretationon Pancasila, that man is one people ${ }^{12}$. It is strengthened by $\mathrm{Ibn}$ Kathir that mankind had initially believed that the Prophet (to believe, to repent, to be true) then to be different, so that he (the ruler, Messenger) was sent ${ }^{13}$. In the context of the paradigm of Pancasila in Nusantara, all of which inhabit the archipelago historically Bhineka Tunggal Ika as a nation namely the nation of Indonesia, the Indonesian language, which is contained in the opening of the 1945 'sconstitution. thirdprinciple of Pancasila is Indonesian unity.

The existence of the practice of the values contained in Pancasila implicates the Life of society, nation, and state in Indonesia. The depletion of sacrifice to the nation, the occupation of the country, did not know about the identity and felt not as a nation of Indonesia. As we pointed out above, Tafsir Pancasila is like a text that will certainly produce various interpretations. Then it is also natural if there are people who bring religious inspiration. At the level of implementation of Pancasila has shown an indication of an empty ideology, the awareness of consciousness is not in demand anymore and the revitalization is left ethical

\section{B. Research Method}

Studies conducted in the study of these studies islibrary research or qualitative descriptive libraries research and use hermeneutic data analysis methods. A library study is a method of collecting data that is directed to search data and information through documents. The written documents, photographs, culture, values, image norms, electronic documents that support the academic process of scientific writing ${ }^{14}$. This type of research, the library research is not merely a matter of reading and noting literature or books as it is often understood by researchers, or writers. What is called

11 Nazwar, “Konsep Ketuhanan ( $\mathrm{T}^{\prime}$ ien) dan Relevansinya dengan Pembentukan Etos Kerja dalam Ajaran Kong Hu Cu (Konfusius)," Desember 2016 22, no. No.2 (364 349M): 349-64.

12 Ahmad Muhammad Yusuf, "Ensiklopedi Tematis ayat alqur'an dan hadits" 22 (t.t.): 499.

${ }^{13}$ IbnuKatsir, Tafsir Alqur'an al Adhin (Kairo: Darul Hadits, 2011), 311.

14 Sugiyono, Metode Penelitian Kuantitatif, Kualitatif (Bandung: Alfabeta, 2009), 93. 
the library research, is a series of activities related to the method of collecting library data, reading and recording and then processing research materials

It is a descriptive qualitative research, a search that seeks to describe a symptom, an event, an event that occurs today that focuses on the actual problem of seeking the truth ${ }^{15}$. Through descriptive qualitative analysis, it seeks to elaborate events or events that are the centre of attention to a contextual object, or a fact later in the analysis in narrative form.

The hermeneutic analysis is to interface messages that are explicitly and implicitly contained in reality in the field. Researchers are interpretations' at once with the complexity of language meanings and the message contained in a language that is unclear to be obvious ${ }^{16}$. The Hermeneutics/interpretation method is applied to systematically capture the meaning of philosophical thinking. The analysis of hermeneutics to manifest the capture of meaning systematically ${ }^{17}$. Based on the statement on the author of the data analysis of religious Tafsir on Pancasila with the collection and preparation of data, namely methodologically and empirically, documents based on categories that correspond to the study, Based on the data obtained, developed data sharpening in the effort to implement Islamic insights in the Indonesian archipelago.

\section{Discussion}

1. Territory of Nusantara

Indonesian nation consists of various ethnic, which has differentreligions, cultures and customs. Nevertheless, the nation of distinction must be realized as something that is always present in every human being as a personal being, and in this matter is ordinary. So that with the unity of the principle of unity that we have, then the difference must be built towards a cooperation in gaining happiness together. With the similarity and the unity of the spirituality principle and the unity of ideology, the difference should be directed by the normative philosophical religion as the basis of a union of the Indonesian territory.

The philosophical interpretation of normative religious interpretation of Pancasila, that man is a unity people, strengthened by Ibn Kathir that man had originally believed or believed. In the context of the archipelago

${ }^{15}$ Noor, J, Metodologi Penelitian Skripsi, Tesis, Desertasi, dan Karya lmiah (Jakarta: Kencana, 2011), 31.

16 Kaelan, Metodologi Penelitian Kualitatif Bidang Filsafat, (Yogyakarta: Paradigma, 2005), 76.

17 Sanusi Uwes, Manajemen Pengembangan Mutu Dosen (Jakarta: Logos, 1999), 17. 
historically as an Indonesian nation. During the time of the Kingdom of Sriwijaya, the Kingdom of Majapahit and the Kingdom of Pasai became a unified, great nation, strong, modern, and feared outside world. In the context of the Indonesian nation who inhabit the archipelago in its essence in fearedin fear by the foreign countries, because the archipelago abundant natural resources, fertile prosperous, "gemahripahlohjinawi" untilothers centuries come to have, the natural wealth.

Our duty and posterity are now and forthcoming to safeguard and preserve it regardless of the way and path. Indonesian people who inhabit the territory of the archipelago by various kinds, tribes, religions, races, groups that are Bhenika Tunggal Ika should be obliged to bind with the ideology of Indonesian nationalism.

The dearness of nationalism in the archipelago can fertilize the knowledge of radicalism in Indonesia, this can be seen from the understanding of the values of Pancasila which is only limited to memorization and not implemented in the daily life. So, the implementation is not up to the goal in order to ward off radicalism ${ }^{18}$. As a result of the values of Pancasila which is not grounded, coupled with the increasingly fertile radicalism movement, the increasing poverty rate and unemployment in Indonesia became the entrance to the development of the understanding of radicalism in Indonesia. The values of science have an integral relationship and become an instrument of understanding that is not in accordance with Pancasila ${ }^{19}$.

The truths value of a religion can be seen from two things: theological truth and historical truth. Theological truths are essentially those that know the creator of the religion itself (read - god). While the historical truths of a religion can be traced from the extent that religion can be beneficial and liberate mankind from the fetters of evil. That in religious understanding, it is absolutely necessary to have evolution that is dynamic, critical, and progressive.

The religious face is why John Caputo, stated in his book, On Religion, that each time he wrote about religion, one must convince him that his subject is not in fact. Any religious-themed book including God Must begin with the bad news for readers that the subject of religion is not there ${ }^{20}$.

18 Dwiyana Achmad Hartanto, "Implementasi Nilai Filosofis Pancasila dan Agama Islam dalam Menangkal Paham Radikalisme di Indonesia,"” 2, no. No 2 (Desember 2017): 307-44.

${ }^{19}$ Faizin, "Integrasi Agama dan Sains dalam Tafsir Ilmi Kementerian Agama RI" 25, no. No 1 (Juni 2017): 19-33.

20 D.Caputo John, Agama Cinta agama Masa Depan, terjmh. Martin Lukito (Bandung: Mizan, 2003), 10. 
According to Ibn Arabi the issue is not that simple, and it could be the question will continue to expand ${ }^{21}$.

On the other hand, along with the increasing of religious studies in the social sphere, it is growing rapidly. This fact shows that there is seriousness of scientists in the study of religions, to pay attention to the performance of the religion in the social sphere. Religious studies are no longer conducted by religious-based colleges alone.

This phenomenon ultimately led to new anxiety, both among the religious people themselves and amongst the scientists. In general anxiety revolves around the issue, how to connect entities that have opposite characters. Each group seeks to convince people to develop their understanding 22 . Religions are considered sacred and the social world of empirical is considered propfan. Various solutions are offered to answer the issue. As Amin Abdullah is the integration-interconnection between religious sciences and the Science of knowledge and philosophy ${ }^{23}$.

While in other contexts the person who avoids the thought of religious evolution in the pretext maintains the purity of religion so as to lose its vital elan and tends to be a force that does not liberate for his pre-believers. Religious knowledge or understanding is not perfect and is valid all the time, because it is tied to a culture system that is also constantly changing. Thus, a growing religious understanding is one form of reform and revival efforts.

Islam as a religion has text that can be seen from various points of view. So that the heterogeneity of interpretation is inevitable. In such a situation, lately there is an effort "primarying" the type of interpretation that raises fanaticism. Such an interpretation is regarded as the undisputed reality of its truthfulness. And this can pose a serious problem considering that there are rarely many interests behind the interpretation ${ }^{24}$. Islamic religious text conditions that are multi-interpretation seem to give opportunities to anyone who has an interest to interpret according to the value of importance. Of course, the interpretation of religious texts is done adapted to their individual needs. As a part of the group that interprets the

21 Amin Abdullah, "Paradigma dan Implementasi Pendekatan IntegrasiInterkoneksi Dalam Kajian Pendidikan Islam," (dalam seminar Nasional, Pascasarjana UIN Suka, Yogyakarta, 2014), 22.

${ }^{22}$ Rohimin, Tafsir Aliran Ideologis Di Indonesia: Studi Pendahuluan Tafsir Aliran Ideologi Sunni Dalam Tafsir Kementerian Agama, Desember 2016, vol. 20, t.t., 169-82.

23 Amin Abdullah, "Paradigma dan Implementasi Pendekatan IntegrasiInterkoneksi Dalam Kajian Pendidikan Islam," 201.

24 Junaidi Abdillah, "Radikalisme Agama: DekonstruksiTafsirAyat-Ayat ‘Kekerasan' Dalam Al-Qur'an” 8, no. No 2 (Desember 2014): 281-300. 
verses of the Qur'an as a means to legalize violent acts in the name of religion on the Earth of Nusantara. The text is installed to move violent acts on behalf of the Lord.

In the concept of avoiding evolutionary evolution even the revolution is caused that the study of religious studies is more promoting the normative. That is a paradigm of theology or faith, which is based on the belief of religious doctrines/doctrines that are sourced on revelation and aims to explain the truth or seek the right of the religion itself 25 .

In acceptance the religious reality, without investigating the reasons and the origin of it is to describe the internal logic of religion that is distinctive and can't be explained by an explanation of other sciences. This is where the normative religion is self-reliant, as is positivistic self-reliance. So, the truth of religion or religious doctrine is not determined by other sciences such as sociology, anthropology also philosophy. Although these sciences can change the stereotype of religion

\section{Religious Interpretations}

Religious interpretation is an interpretation of religious teachings manifested in religious practice. Interpretation of religion in Pancasila culture can be said to be a kind of interpretation of the matter that is the result of understanding or interpretation of religious teachings, both from the Qur'an and hadith. Since the beginning of the spread of Islam, this type of religious interpretation is very effective in spreading Islamic teachings, especially in the archipelago that is difficult to understand the interpretation of the Qur'an and hadith. Islamic Scholars at that time taught the teachings of Islam using interpretation in the cultural framework ${ }^{26}$.

But it needs to be underlined that the meaning associated with the core information in the first principle is not necessarily the same as the morphological meaning, even objectively different at all. The meaning of the true Godhead cannot be separated by the meaning of religion in Indonesia, because the materialist the (because of the material) is an Indonesian nation that since ancient times has had religious values. Therefore, the meaning of the first principle should be explained on the basis of materialist the (the form of material) in the process of forming Pancasila. This is given that the process of forming Pancasila as well as the

25 Imam Suprayogo, Metodologi Penelitian Sosial-Agama (Bandung: Remaja Rosda Karya, 2003), 20.

${ }^{26}$ Marzuki, "Tradisi Meugang dalam Masyarakat Aceh: SebuahTafsir Agama dalam Budaya" 16, no. No 2 (Desember 2014): 216-30. 
result of a deep contemplation of the soul is also a result consensus philosophy (Philosophical consensus) and political consensus.

According to Mudzhar, there are five religious symptoms that can be researched. First scripture or manuscripts or doctrinal resources and religious symbols. Both devotees, leaders, religious princes are thought, attitudes, attitude as an actualization of religious teachings and beliefs. Third, rites, institutions and worship. The four tools such as mosques, churches, bells, temples, peci and such. Fifth, religious organizations where religious believers gather and play roles, such as Muhammadiyah, NU, Persis, Catholic Church and others ${ }^{27}$.

Socio-religious symptoms are an abstract symptom and verbalism, these symptoms can be phrases, attitudes, symbols, ideals, emotions that are appreciated and the thought by the culprit is considered to have a relation to life with the embodiment of the religious teachings or doctrines of the religious teachings he believes. Therefore, social reality in social studies in more and more struggling with the social constructionconcept.

According to Talcot Person more emphasis on the harmony, regularity and balance in a social system, there are values and norms that become the benchmark and behavioural reference for each member of the community. The values are mutually agreed. With the value of being a common benchmark then the community will happen regularity. The value should always be maintained so that the community remains in the regularity and harmony ${ }^{28}$.

Meanwhile, according to Merton when people feel satisfied with the values, the community will appreciate it. The value is the benchmark with important factors to encourage social integration. When people are dissatisfied with their values, a community has no binding factor to each other, encouraging social integration ${ }^{29}$. The growth and growing religious values are a social institution that influences the reality of society.

The creativity of the Indonesian Muslim community to reconcile Islamic doctrine with local wisdom and secular values (Pancasila) produces a model of cultural legacy. Hence Islamic Law is not to be seen as an antithesis of Pancasila. On the contrary, they can interact each other resulting in the interdependent enrichment and development of Indonesian national law ${ }^{30}$.

27 Imam Suprayogo, Metodologi Penelitian Sosial-Agama, 20.

${ }_{28}$ Maman. U.kh, Dkk, Metodologi Penelitian Agama (Jakarta: RajawaliPerss, 2006), 129.

${ }^{29}$ Maman, 130

${ }^{30}$ Maman. U.kh, Dkk, Metodologi Penelitian Agama, 30. 
The creativity of Islamic insights in Indonesia to reconcile the Islamic doctrines with local wisdom and Pancasila values produces a model of cultural heritage. Hence Islam should not be seen as the antithesis of Pancasila. On the contrary, they can interact with each other resulting in the enrichment and development of Indonesia's national philosophical. As Pancasila as the benchmark value in the community, because Pancasila is a result of thinking that also summarizes the characteristics of the personality in the Indonesian culture and the life of humanity as a whole. In other words, Pancasila is a new development in the life of Indonesia in the course of its long history ${ }^{31}$. Pancasila was formulated based on the belief that there are already values, embedded and rooted and remain valid in Indonesian society today ${ }^{32}$.

Pancasila continues to have academic problems, especially the problem of interpretation that has a consequence on the problem of implementation in State life. So the implementation of Pancasila is in the problem of interpretation. The history of Pancasila has been giving lessons that Pancasila is open to various interpretations ${ }^{33}$.

Even an interpretation of Pancasila can be used as an ideological legitimacy of power. As a value of common goodness, what is Pancasila and the content of meaning that exists in each of its principle, must be socialized and internalized to all citizens including citizens who are ruling the state organizers. For the purposes of "national and character" as well as the interests of the shared community, the country according to the view of the communitarian are in the interest of socializing shared values, common virtues or common kindness of citizen

Based on the cultural structure of the Indonesian nation gained a basic moral in shaping the life of society. The basic Moral is not only useful for personal, even social life, for the life of state ideology, politics, culture of national resilience 34

Thus, the spirit of Nusantara re-ignited. This means that there is value lost so that the harmony of the religious people becomes threatened. Because the Pancasila clearly gives a mandate to keep mutual respect

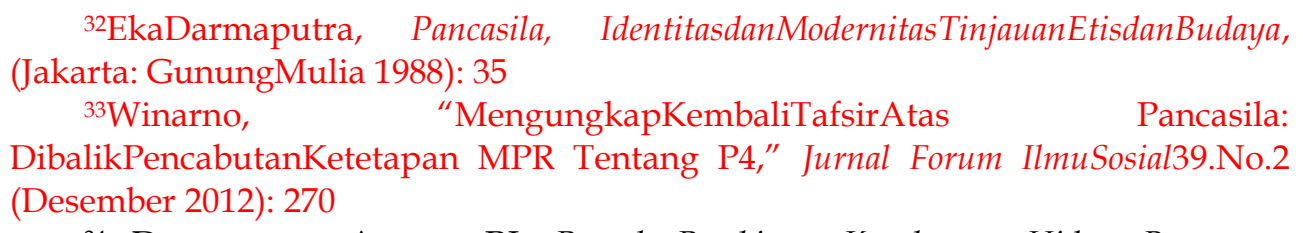

31Kansil, SistemPemerintahan Indonesia, edisirefisi, (Jakarta: BumiAksara, 2003): 13

34 Departemen Agama RI, Proyek Pembinan Kerukunan Hidup Beragama, Pedoman Dasar Kerukunan Hidup Beragama (Jakarta, 1982), 3. 
among religious believers. Back to light the spirit of Pancasila is an important capital in maintaining sovereignty, integrity of homeland. If not done mental spirit of the nationality of Pancasila, then the spirit will be easily fragile and replaced with foreign ideology that does not match the variety of life in Indonesia ${ }^{35}$.

\section{Implementation of Islamic Insights}

As an open Ideology, Pancasila has an adaptative ability to change the era without the burden of the principle of sacredness such as religion. The principles of Bhineka Tunggal Ika exist, allowing differences, politics, beliefs, religions, beliefs, cultures in the unity of the community in Indonesia through the cultural culture without distinguishes and dissemination of the virginity. Substantial Pancasila is a mixture of religion (belief in one God), culture ofBhenika Tunggal Ika.

In accordance with the character of the religion evolutionary that must be endowed, the tradition of criticism and the appearance of the heterogeneous interpretation becomes a reasonable and inevitable. This tradition is aimed at religious prophetic roles as moral force and liberation through the behaviour of the adherents can appear again to the surface. The diversity of interpretation also has a positive value as an effort contextualise the religious texts on the humanitarian problems of today.

In the appearance of the diversity of religious interpretations, the method of deconstruction that was triggered by Jacques Derrida is worthy of alternative paradigms and workways. The method which was originally used in this field of literature and philosophy, aims to dismantle, unpack, or diluting any type of structure. Speech writing becomes the writing of the actual greeting as a series of writing logos or think analysing said, where each step requires interpretation ${ }^{36}$.

In the field of religion, deconstruction of this text allows us to dismantle the monopoly of interpretation of certain authorities that assert the "truth" on behalf of God, State or ruler. So, the definition and practice of searching "the truth" becomes democratic and paradigm Anthropocentric. In this case, man becomes the centre of interpretation that seeks to dig a variety of truths objectively. Pancasila as the ideology of the country and the unitary State of the Republic of Indonesia is formed from the results of Consensus or National Agreement (ahdi) and state of testimony (shahadah) socialization concept of the country is not explicitly contains elements

35 Febri Hijroh Mukhlis, “Teologi Pancasila: Teologi Kerukunan Umat Beragama,"," Jurnal Fikrah 4. No2 (Desember 2016): 171-86.

36Kaelan, Metodologi Penelitian Kualitatif Bidang Filsafat, 251. 
development in order to realize the welfare goals of the nation and State in various aspects of life, so that it can be a concept of the state Pancasila socialization of the concept of state Pancasila as Darul Ahdi WaSyahadah ${ }^{37}$.

As Muhammad Arkoun achieved liberal thinking by deconstruction (unpacking) is a ijtihad using the historical approach ${ }^{38}$. Also, contemporary thinking will need to open up new insights, through a systematic crosscultural approach to fundamental issues ${ }^{39}$.

The religious evolution that appreciates the plurality of itself emphasizes borrowing the term Mohamed Arkoun - historicity of logos in the reading of the text. That is, in the reading of religious texts is absolutely noted the time span of emergence, complexity, and the background of the ideology contained therein.

In the context of Indonesia, Pancasila is an expression of the collective identity. As a collective identity, Pancasila has no ends and always inthe process of being and find themselves in a new way ${ }^{40}$. Pancasila as the ideology and collective identity of the nation of Indonesia is only empowered if it is accepted by all regions of Nusantara. Indonesian people are part of a global citizen and take part in the global identity formation process as well. Because Pancasila can survive not by maintaining its authenticity, but in its ability to communicate with other ideologies. Reinterpreting Pancasila in light of the ideology is one of the important efforts to preserve the relevance of Pancasila

In that regard John Mill was more on reviewing the critical text (textual criticism). To the new agreement by collecting variants of readings from meant to not give absolute verdict true to an interpretation, but rather to perform a critical understanding and analysis of an interpretation ${ }^{41}$.

37 Muhamad Salisulkhakim Muhamad Salisulkhakim, MediTrilaksonoDwiAbadi, " Medi Trilaksono Dwi Abadi, "Sosialisasi Konsep Negara Pancasila," Jurnal Pancasila dan Kewarganegaraan 4, No 1 (Januari 2019): 111.

38 Adnin Armas, Metodologi Bibel Dalam Studi Alqur'an (Jakarta: GemaInsani, 2007), 65 .

39 Muhammad Arkoun Azim Nanji, Rentinking Islam today, dalam maping Islamic Studies, Geneology, Continuity and Change (Berlin: Mouton de Gruyter, 1997), 237.

${ }^{40}$ Otto Gusti Madung, "“Pancasila dalam Pusaran Diskursus Liberalisme versus Komunitarisme," Jurnal Jurnal Studi Islam dan Humaniora, 2015, 13, No 2 (t.t.): 312-36.,

${ }^{41}$ Faiz Fahruddin, Hermeneutika Alqur'antema-tema kontroversial (Yogyakarta: eLSAQ Press, 2005), 16., 
According to FaridEsack, the interpretation of such interpretations cannot be completely independent based on mere text, but it is certainly related to its historical content, both at the time of the text appearing and when the text is interpreted. For, a sacredness makes man shackled to single truth and acceptance without a reserve of religious text interpretation. In fact, the emergence of text in the past is certainly not separated from the author's political and ideological dimensions. That the reality of life is never singular and one of the same, but always multi dimensions and can be said that is a very necessary realization in the current reform era. Muhammad Arkoun's view of achieving liberal thinking by deconstruction (unpacking) is a ijtihad using the historicity approach $^{42}$. Also, contemporary thinking will need to open up new insights, through a systematic cross-cultural approach to fundamental issues. Worthy of use as a cornerstone of theory in research to be conducted.

In detail we observe their actions, conduct and movements (both word and deed), then we will know that indeed what they do is actually not for the sake of religion, scripture, let alone God. More precisely, the violent actions they do are often, if not always, to defend the interpretation (about) the non-religious religion itself, to defend the interpretation (about) scripture is not the scripture itself, as well as to defend the interpretation about God, not God Himself. Not limited to that, even often communal violence among religious religions or violence over certain religions is triggered by factors that have absolutely no relationship with the teachings, doctrines, and religious norms. For the sake of egoism and the lust of violence is also often to obey the lust and selfishness of a particular group of religious people, there is no correlation with the fundamental doctrines of religion. The religious texts are simply twisted or used as a correct as if the violent and ridiculous actions they do get "mandate" or blessing from God43.

The concept of Islamic insight is most widespread and the repeater "rahmatallilalamin". About worship, sharia, rulings and creed and the natural universe and its ISIS, but the authors restrict in this study. So various views appear to develop, to deconstruct Islamic Insight in the framework to convey the contemporary of Irian, which is adapted to the development of the era especially on the local culture that is in the Earth of Indonesian archipelago (nusantara).

${ }^{42}$ Farid Esack, Qur'anPluralisme and Liberation (Oxford: One World, 1997), 50.

43 Ahmad Muttaqin, Paradigma Pancasila dalamTafsir, 2016, 43, Al-Qur'an,", www.nu.or.id/post/read/68727/ paradigma-pancasila-dalam-tafsir-alquran. 
In the text of the study of Islamic insights to be implemented in the Nusantara region of the author of the faith (aqidah) because of the creed of a system and the governance that regulates human livelihoods in a variety of relationships between humans and God, our fellowmen, and the relationship between human and other nature. And aim to seek God's mercy for all the nature of world and supra-nature happiness. It is a revelation handed down by Allah $t$ to his messenger to be conveyed to mankind in every nation ${ }^{44}$.

As the methodology of interpretation is the most famous of the Pancasila or the paradigm of Pancasila, in the Surah (Albaqarah: 312), that man is a people who are one. It means God and unity for all beings on Earth. Essentially all mankind is subject to an extraordinary power that overcomes their lives. The submission is then manifested in the form of rites that vary between one and another. Therefore, he assumed that in fact all mankind from generation to generation were monotheists. The argument is strengthened by Q.S. al-Tawbah, 10:19, and Q.S. al-Baqarah, 2:203 The unity of God is the result of the evolution of every nation that departs from the limited assumption of God to achieve the same conclusion $H$ (2): 120. According to him, so far people will justify others right or wrong only seen from the class where he came from ${ }^{45}$. As long as the person follows God's direction, the person is not to blame just because he follows the group that has been considered wrong.

The text of the interpretation of the Holy Quran is Q.S. Ali Imran: 64 "say oh expert of the book, come to hold to KalimatunSawa... ". If it refers to the Arabic lexicon, the word "sawa'un" may mean fixing (hasuna), reconciling (aslaha) and swinging (waffaqa).

Pancasila is referred to as the basis of State philosophy, PhilofofischeGronslag from the country contains the consequences that in every aspect of the implementation of the State must conform to the values of Pancasila. "kalimatunsawa"in the context of Indonesia must be understood by the paradigm Pancasila. Thus, "kalimatunsawa" is jointly upholding the value of deity by acknowledging that all adherers of religion, even with different religious shirts have the same vision of Deity, together to fight for the values of humanity, Maintaining the unity of the Unitary Republic of Indonesia (NKRI), championing the welfare of the

44 Endang Saifuddin Anshari M.A, Wawasan Islam-pokok-pokok pikiran tentang paradigma ESistem Islam, (Jakarta: Penerbit Gema Insani Press, 2004), 141.

45 Toipah, “Tafsir Al-Qur'an Atas Problematika Lintas Agama: Kajian AtasTafsirTarjuman Al-Qur'an Karya Mawlana Abul Kalam Azad,"," Jurnal QOF 1, No 1 (Juni 2017): 65-77. 
people both socially and economically, eradication of poverty in efforts of implementing the value of Justice on Indonesian Archipelago.

Pancasila as the basis of philosophy of the state is essentially a source of value for the nation and state of Indonesia. Then all aspects in the organizing of the state are based and covered by the values of Pancasila. Thus, the Pancasila as the basis of State philosophy is essentially the foundation national spirituality ${ }^{46}$.

Thus, all life of Indonesia based on Pancasila, is held in a unity relationship with the realization of psychiatric life in the form of life adjustment of State with the values of human life, which is concluded in The principle Kerokhanian Pancasila, namely the truth and reality, the beauty of psychology, goodness or worthiness (morality), humanity, human nature and human life as a creature of God.

Many people question actually in state life today, actually the country's goal to achieve democracy, or to attain the welfare of all people. Human beings form a living fellowship called the State, is to achieve the purpose of living together that is a social welfare (welfare of all people), by realizing a justice. To expand the sovereignty system whose substance is sourced from the people. ${ }^{47}$

BhinekaTunggalka is a adhesive Indonesian nationalism roots of Indonesian nationality since its inception is based on a determination that emphasizes the importance of common ideals, in addition to recognition and appreciation of differences as a binder to the nation It is clearly seen in the motto of Bhinneka Tunggal Ika, which emphasizes the importance of equal ideals and as well as the perfection of the nation. 48

The term Islam Nusantara (writer: Islam in Nusantara) here refers to the fact that the history of spreading Islam in the archipelago territory by means of cultural approaches, not with rigid and harsh doctrines, Islam Nusantara is the embracesa culture, Preserving cultures, respecting cultures, not even muzzle cultures. Said Aqil also added Islam Nusantara has a character friendly, anti-radical, inclusive and tolerant instead of Islamic Arabs who always conflict with fellow Muslims and civil war ${ }^{49}$.

In its development, Islamic religion received positive response from Indonesian society so that Islam experienced rapid development once to be

${ }^{46}$ Kaelan, Metodologi Penelitian Kualitatif Bidang Filsafat, 106.

47 Kaelan, 656.

48 Abd Mu'id ArisShofa, "Memaknai Kembali Multikulturalisme Indonesia Dalam Bingkai Pancasila," Jurnal Pancasila Dan Kewarganegaraan 1, No 1 (Juli 2016): 50-59.

49 Mohamad Guntur Romli, Islam Kita, Islam Nusantara Lima Nilai Dasar Islam Nusantara (Ciputat: Ciputat School, 2017), 17-18. 
able to take over the position and role of two Hindu-Buddhist giant religions, as a sign of the victory of Islam amazing in the competition of gaining community trust. Ahmad SyafiiMaarif stated that the victory of Islam was phenomenal, two old religious giants that had existed centuries in the archipelago were eliminated in such a way.

The context of Islamic insights in the Indonesian archipelago is described as normative teachings derived from God are accommodated and implemented into cultures derived from human beings without loss of their own identity. Thus, the Arabization as has been asserted is not necessarily suited to the needs ${ }^{50}$. So that the Islamic insight in Nusantara is trying to make religion and culture do not beat each other, but to make it in the pattern of religious reason that no longer take its authentic andreligion try to bring together the bridge that has been between religion and culture.

\section{Conclution}

The religious interpretationon Pancasila is in implementing Islamic insight in the Indonesian archipelago with a methodological and empirical approach of what is happening with the phenomenon contextually. Pancasila as the foundation and view of the life of Indonesia in the Indonesian archipelago that is currently happening only as text only, or loss of identity as a philosophy of life. In the context that should lead to the best path to return the Indonesian ideology of Pancasila. Islam teaches for mutual respect and mutual tolerance, a religion that teaches the complainant to love one another, loving and nurturing regardless of race, nationality, and social structure

Islamic insights in Indonesia to reconcile Islamic ideology with local wisdom and values (Pancasila) produce a model of cultural heritage. Hence Islam should not be seen as the antithesis of Pancasila. Conversely, it can interact with each other resulting in the enrichment and development of the national philosophical Indonesia with the concept Bhineka Tunggallka, with the concept of youth oath, speaking in one Bahasa Indonesia, one Indonesian nationality in the one house Unitary Republic of Indonesia (NKRI) the price of death in the struggle to reach the blood efflux.

Implementation of Islamic insight in Indonesian archipelago with peace in order to embed Islamic values, goodness in society and religious life. The population of Nusantara Islands received it with open arms and no one opposed to the inclusion of Islamic religion in Nusantara

50 Hanum Jazimah Puji Astuti, Islam Nusantara: Sebuah Argumentasi Beragama dalam Bingkai Kultural,", vol. 2, No.1 (Jurnal INJECT: Interdisciplinary Journal of Communication, 2017). 
archipelago. Islamic insights contain guidance and guideline in community and state life. Islamic insight on nusantara archipelago through the principle of consultation, united, sovereign, justice, equality, towards prosperity[.]

\section{REFERENCES}

Abd Mu'id ArisShofa. "Memaknai Kembali Multikulturalisme Indonesia Dalam Bingkai Pancasila." Jurnal Pancasila Dan Kewarganegaraan 1, No 1 (Juli 2016): 50-59.

Ahmad Muhammad Yusuf. "Ensiklopedi Tematis ayat alqur'an dan hadits" 22 (t.t.).

Ahmad Muttaqin. Paradigma Pancasila dalamTafsir, 2016. Al-Qur'an,", www.nu.or.id/post/read/68727/paradigma-pancasila-dalam-tafsiralquran.

Amin Abdullah. "Paradigma dan Implementasi Pendekatan IntegrasiInterkoneksi Dalam Kajian Pendidikan Islam,." Yogyakarta, 2014.

Atosokhi Geanoor Rahcmat Antonius, dan Panca Yuni Wulandari AntoniaAtosokhi Geanoor Rahcmat Antonius. Relasi dengan Tuhan. Jakarta: Gramedia, 2004.

Azim Nanji, Muhammad Arkoun. Rentinking Islam today, dalam maping Islamic Studies, Geneology, Continuity and Change. Berlin: Mouton de Gruyter, 1997.

D.Caputo John. Agama Cinta agama Masa Depan, terjmh. Martin Lukito. Bandung: Mizan, 2003.

Departemen Agama RI. Pedoman Dasar Kerukunan Hidup Beragama. Jakarta: Proyek pembinaan kerukunan DEPAG RI, 1984.

- - - . Proyek Pembinan Kerukunan Hidup Beragama, Pedoman Dasar Kerukunan Hidup Beragama. Jakarta, 1982.

Dwiyana Achmad Hartanto. "Implementasi Nilai Filosofis Pancasila dan Agama Islam dalam Menangkal Paham Radikalisme di Indonesia,"'" 2, no. No 2 (Desember 2017): 307-44.

Endang Saifuddin Anshari M.A,. Wawasan Islam-pokok-pokok pikiran tentang paradigma ESistem Islam,. Jakarta: Penerbit Gema Insani Press, 2004.

Faiz Fahruddin. Hermeneutika Alqur'antema-tema kontroversial. Yogyakarta: eLSAQ Press, 2005.

Faizin. "Integrasi Agama dan Sains dalam Tafsir Ilmi Kementerian Agama RI" 25, no. No 1 (Juni 2017): 19-33.

Farid Esack. Qur'anPluralisme and Liberation. Oxford: One World, 1997.

Febri Hijroh Mukhlis. "Teologi Pancasila: Teologi Kerukunan Umat Beragama,"." Jurnal Fikrah 4. No2 (Desember 2016): 171-86. 
Hanum Jazimah Puji Astuti. Islam Nusantara: Sebuah Argumentasi Beragama dalam Bingkai Kultural,". Vol. 2, No.1. Jurnal INJECT: Interdisciplinary Journal of Communication, 2017.

IbnuKatsir. Tafsir Alqur'an al Adhin. Kairo: Darul Hadits, 2011.

Imam Suprayogo. Metodologi Penelitian Sosial-Agama. Bandung: Remaja Rosda Karya, 2003.

Junaidi Abdillah. "Radikalisme Agama: DekonstruksiTafsirAyat-Ayat 'Kekerasan' Dalam Al-Qur'an' 8, no. No 2 (Desember 2014): 281-300.

Kaelan. Metodologi Penelitian Kualitatif Bidang Filsafat,. Yogyakarta: Paradigma, 2005.

LembagaKetahanan Nasional (Lemhanas). Ketahanan Nasional. Jakarta: Penerbit PT Balai Pustaka Dengan Lemhanas, 1997.

Maman. U.kh, Dkk. Metodologi Penelitian Agama. Jakarta: RajawaliPerss, 2006.

Marzuki. "Tradisi Meugang dalam Masyarakat Aceh: SebuahTafsir Agama dalam Budaya" 16, no. No 2 (Desember 2014): 216-23.

Moerdiono. Pancasila sebagai Idiologi Dalam berbagai Kehidupan Berbangsa dan Bernegara. Jakarta: Bp. 7 Pusat, 1992.

Mohamad Guntur Romli. Islam Kita, Islam Nusantara Lima Nilai Dasar Islam Nusantara. Ciputat: Ciputat School, 2017.

Muhamad Salisulkhakim, MediTrilaksonoDwiAbadi, ", Muhamad Salisulkhakim, Medi Trilaksono Dwi Abadi. "Sosialisasi Konsep Negara Pancasila." Jurnal Pancasila dan Kewarganegaraan 4, No 1 (Januari 2019): 1-11.

Muhammad Ali al Shabuni. al Tibyan fi Ulum al Qur'an. Dimaskus: Makatabah Al Ghazali, 1981.

Muhammmad Amin Suma. Studi Ilmu-Ilmu Alqur'an. Jakarta: Pustaka Firdaus, 2001.

MutisThoby. Perdamaiandan anti Kekerasan, Merajut Mozaik Budaya bangsa. Jakarta: UniversitasTrisakti, 2007.

Nazwar. "Konsep Ketuhanan ( $T$ 'ien) dan Relevansinya dengan Pembentukan Etos Kerja dalam Ajaran Kong $\mathrm{Hu} \mathrm{Cu}$ (Konfusius)." Desember 2016 22, no. No.2 (364 349M).

Ni WayanGateri. "Ajaran Agama Hindu Dalam Peningkatan Kerukunan Menuju Keharmonisan Hidup" 2, no. No. 2 (Agustus 2016): 93-108.

Noor, J. Metodologi Penelitian Skripsi, Tesis, Desertasi, dan Karya lmiah. Jakarta: Kencana, 2011.

Otto Gusti Madung. "“Pancasila dalam Pusaran Diskursus Liberalisme versus Komunitarisme." Jurnal Jurnal Studi Islam dan Humaniora, 2015, 13, No 2 (t.t.): 312-36. 
Rohimin. Tafsir Aliran Ideologis Di Indonesia: Studi Pendahuluan Tafsir Aliran Ideologi Sunni Dalam Tafsir Kementerian Agama. Desember 2016. Vol. 20. No2 vol., t.t.

Sanusi Uwes. Manajemen Pengembangan Mutu Dosen. Jakarta: Logos, 1999.

Sugiyono. Metode Penelitian Kuantitatif, Kualitatif. Bandung: Alfabeta, 2009.

Toipah. "Tafsir Al-Qur'an Atas Problematika Lintas Agama: Kajian AtasTafsirTarjuman Al-Qur'an Karya Mawlana Abul Kalam Azad,",," Jurnal QOF 1, No 1 (Juni 2017): 65-77.

Tri Yuliana Wijayanti. “Konsep Kebebasan Beragama Dalam Islam Dan Kristen" 17, no. No.1 (Juni 2016): 16-22.

YuanggaKurnia Y. "Fenomena Kekerasan Bermotif Agama di Indonesia" 15, no. 2 (Desember 2017): 205-17. 
116 | AKADEMIKA, Vol. 24, No. 01 January - June 2019 